\title{
Impact of NTFP Harvesting in Forest Conservation
}

\section{Resham Bdr. Dangi ${ }^{1}$}

\begin{abstract}
Regardless of size, Nepal is famous for floral and faunal diversity in the world. Out of 15,000 identified plant species in this country, more than 2000 plants have medicinal properties and more than 100 plant species are in commercial trade. There is growing concern in governmental and non-governmental organization to promote NTFP for improvements of rural livelihoods and forest conservation. However, field evidences do not demonstrate its meaningful contribution in forest conservation objective. This paper attempts to appraise the bottleneck issue in maintaining Maximum sustained yield (MSY) of viable NTFPs. The analysis is more focused on production characteristics rather than demand and institutional characteristics of NTFPs. Finally, the paper concludes by recommending few potential options for improvement. The suggested intervention includes preparation of new inventory guideline; improve forestry governance, training and extension for collectors, capacity building for forestry professional, and support for strengthening market infrastructure.
\end{abstract}

Key Words: Non-timber forest products (NTFP), Market demand, Harvestable quota, Maximum sustained yield (MSY), Ecological impact and forest governance

\section{The Context}

Nepal occupies a very small portion of global land surface, but her contribution in bio-diversity conservation is very important. High topographic variations, even within a very narrow north -south transect, offers significant level of species, ecosystem and genetic level diversity. It is estimated that there are more than 118 ecosystem types where more than 15,000 identified plant species inhabit as a wild resources. Out of that about 2000 plants have medicinal properties, and over 1463 species are used locally in Nepal (Shrestha et.al. 1999).

Nepal has about 29 percent of the surface land occupied by the forests. Forests produce various commodities and services that are either directly consumed by the households without going to the formal market or traded in a market for cash income. Non-timber forest products (NTFP) are one of those forest products that are either directly consumed as a factor of production to household economy, health care, food supplement etc or traded as a commodity in local, regional, national and international markets for cash income. In this paper NTFP terminology represents - all products or specimens obtained from the plant resources offered by the natural forests excluding wood products.

There has been growing concern in governmental, non-governmental and local communities

\footnotetext{
Project Manager, Terai Arc Landscape Program,Dhangadhi,reshamdangi@hotmail.com
} 
to promote NTFP to harness its meaningful contribution in small-scale rural livelihood improvements. Nepal government has explicitly mentioned its importance in poverty alleviation related policy documents and national development plans. Since major source of NTFP is natural forests, GoN has paid little attention to enhance its production outside the natural forests

It has been assumed that the NTFP collection from the natural forests will have minimum damage to the forest ecosystem as compared to the timber logging. Both planners and practitioners assume that it is a low impact forest uses that comply with the forest conservation objectives. However, it has failed to demonstrate its meaningful contribution to improve rural livelihoods and to satisfy forest conservation objectives in Nepal.

After 90s, NTFP market has globally grown-up for increasing demand of natural products and alternative medicines among the western consumers. Approximately one fourth of the world's poor and $90 \%$ of the poorest rely significantly on forests for their livelihoods (World Bank 2001). FAO estimates that 80 percent of the populations of developing countries use NTFP to meet their needs in health and nutrition (FAO, 1997). The estimated market value of herbal medicine alone (a large proportion of which is collected from the wild) is about US \$ 14 billion (Secretariat of CBD, 2001).

In Nepalese context, about 10,000 - 15,000 MT of plant products of more than 100 Species are annually collected and exported to India (Edward, 1996); involvement of rural households in NTFP collection is more than 470000 and poor people's involvement in this activity is even higher (Olsen, 1998). NTFP database of period 1998- 2005 indicate that annual NTFP (herbs and medicinal plants) collected from the state regulated forests ranged from 1590-4812 MT ; and NRs 12-27 million royally was collected by the GoN . Whereas royalty collected from timber alone in year 2006/07 was about NRs 326 million compared to the 16 Million from NTFP in that year (DoF, 2007). Therefore, contribution of NTFP in national economy is not as significant as timber, though its support in livelihoods is evocative.

Peters et.al. (1989) estimated that the long term economic returns from the forests managed for Non timber Forest products (NTFP) in tropical forests is greater than the net returns from timber or forest conversion to agriculture. This proposition attracted many forest conservationists in favor of NTFP management. Many developing countries like Nepal have initiated to allocate financial and human resources in NTFP promotion activities. But field observation reveals that the involvement of people at subsistence economy in NTFP collection activity is much more significant than the better-off families. This is why poor households set high value in NTFP resources. However, in market economies the value for NTFP decreases and it is replaced by other non-use values like carbon sequestration or option value or existence value etc.

There have been mixed response regarding impact of NTFP harvesting in forest environment and livelihoods. There are many inquiry reports produced by the government agencies that query on biological, economical and institutional impacts of NTFP harvesting and trade. Biological aspect involves production characteristics that include impact at various levels- species, genetic and ecosystem. The economic aspect is concerned with fiscal policy, income distribution and 
demand characteristics. The institutional aspect is concerned with forestry governance, organizational capability, policy instruments and professional integrity.

It is a universal trend that when market price suddenly increases then the extraction rate also accelerate to meet the market demand that often put selected species (high value) under threats of extinction. Lichen, Kaulo, Yarsagumbu, Jatamashi and Orchids are few commercially important plant species that have been seriously threatened due to weak regulatory instruments to cope sudden changes in international market demand. The authorities are still issuing collection permits without proper understanding of the key-ecological attributes of those species.

The permissible quotas for each commercially viable forest products are used to be mentioned in the Initial Environment Examination (IEE) report and district forest management plans. Unfortunately such prescriptions are neither based on sound scientific knowledge nor satisfy formal resource inventory procedure. The authorities provide collection permits for approved volume, mentioned in the IEE and management plans, without investigating demand, supply and institutional characteristics of those products.

In the absence of adequate information and poor regulatory mechanisms, the collectors have incentive to over extract selected high value species for maximum resource rents. Due to poor governance and weak professional integrity, government has failed to harness optimum return from NTFP harvesting and trade. However, there is still opportunity to scale-up benefits from NTFP by practicing sustainable management practices.

\section{Post-mortem of Current Practices}

Harvesting of NTFPs can have a positive or negative impact on the conservation of biodiversity (Bhattarai \& Croucher, 1996). In the absence of proper management and control in the collection and trade, NTFPs are becoming vulnerable, endangered and even extinct (Acharya, 2000). A sound knowledge on plant ecology, species distribution, reproductive system, growth characteristics, and demand structure will better equip the authority to regulate collection activities in an effective and efficient manner.

There has been divergent opinion between foresters and non-foresters regarding the appropriate resource inventory methods. Foresters stress in a formal and scientifically sound method; whereas non-foresters are in favor of an informal method which is friendly to traditional knowledge and local capacity. The challenge for forester is to optimize the production function of NTFP to meet the objective of sustainable rural livelihoods improvement and forest conservation.

After World War, global demand for construction timber had suddenly increased. That attracted forestry academia to focus their research and education in application of biometrics, economics and silviculture principles in fixing optimal rotation age of timber trees to maximize profit. Consequently, conventional forestry education granted high priority in maximizing production function of timber products not the NTFPs. For that reason, conventional foresters sharpen themselves for timber management and overlooked NTFP as a minor forest product. 
Since then, foresters master themselves in applying theory of Maximum Sustained Yield (MSY) in fixing annual timber harvesting quotas. The concept of MSY is based on the principle of adjusting harvesting effort as per change in growth rates or death rates of timber tree. The theoretical concept is same for NTFP as well to prescribe sustainable harvesting quota. This is an important feature of renewable resources to maintain sustainable production of goods and services for current as well as future consumption.

However, existing field practices raise a million dollar question- Does NTFP harvesting really satisfy MSY test criterion? The authority does not have adequate information about species population, species distribution, growth/ mortality rate, and age-class distribution for even viable NTFP species. Therefore, field evidence does not provide sufficient verification to accept assumption of positive contribution in forest conservation objective.

NTFPs include products like leaves, bark, fruit, roots, flowers and whole plant. The collection of ripe fruits and leaves may cause high mortality but have low adverse impact in regeneration potential. If whole plant uprooted or felled to collect leaves and seeds instead of plucking from the twigs and branches then it might lead to unsustainable harvesting. Collection of roots, whole plants and barks are even more sensitive to plant growth. The field technicians require better understanding of yield regulation technique to regulate harvesting activity effectively.

Wiersum (1999) classify NTFP in two broad category based on the management characteristics; viz. supply and demand characteristics. Supply characteristics include attributes regarding regeneration potential, domestication and production enhancement. Whereas demand attributes include consumption behavior, market structure and value addition potential.

The sustainable harvesting of NTFP is highly sensitive to market price, demand size, and institutional setup of monitoring organization. If market demand is very high at reasonable price then harvesters will have incentive to over exploit resource to collect maximum resource rent available at local market. Sudden increase in demand or market price often exhausts species population and finally show the way to extinction at local level. In such circumstances government can adopt pricing policy to regulate harvesting level by artificially crating scarcity value (high royalty rate) to shift market demand. We have bitter experience with Yarsagumbu, Panchaule and Sungabha species; this instrument did not due to weak regulatory instrument. If there is high potentiality of species loss then extensive program for domestication or substitution could be feasible option for conserving that species in long-term.

If there is low level of exploitation due to low price or high substitution effect then there is nothing to worry about those species. This is very much rational because we can not spare our scarce resources in conserving such species. Between these two extreme situations, majority of species fall under the medium category that needs technical effort for suggesting management prescription. In this domain a suitable institutional framework needs to be created to regulate MSY.

There could be three potential options in sustainable management of NWFP i.e. forest centered, people centered and hybrid approach. Wiersum (1997) identifies three categories of indigenous NTFP management practices: 
1. Maintenance of the resource stock through controlled utilization and production,

2. Stimulation of the production of required products within existing vegetation, and

3. Stimulating regeneration of valued species.

\section{Challenges in Yield Regulation}

Field level forestry technicians are using community forestry inventory guideline to calculate growing stock of timber as well as non-timber forestry products. The results are based on the information collected from the stratified systematic random sample plots. To minimize missrepresentation, three stage nested sample plots are laid as a pseudo-replication in each sample points. This sampling design is based on the conventional forest inventory techniques. However, this is not an effective and efficient technique for NTFP inventory due to following reasons:

- Many species are rare and are distributed in patches

- Many species are seasonal and hard to distinguish, so it may not be compatible to forest inventory sampling technique,

- Practical difficulties in determining volume of Annual Allowable Harvest (AAH)

This is a common problem in all developing countries; as Jerry Wong (2000) demonstrates in his extensive literature review that only few resource assessments methods are scientifically correct. There are other alternative methods available like- forecasting, population viability modeling, experimental designing etc, but these methods are limited to research work only. No matter what methods are used; the basic premise should be to recommend harvesting level at which the rate of resource extraction remains below the annual augmentation rate

In addition to resource inventory issues there are other important factors as well that have been equally important in sustainable harvest of commercially viable NTFPs from the natural forests. They are as follows:

- Inadequate knowledge about the phenology, ecology, and regenerative capacity of the important species.

- Poor knowledge on domestication, appropriate harvesting time, harvesting techniques, post- harvesting practices and improved processing techniques for value additions.

- Lack of standardized selling units in practice by collectors.

- Weak market linkages between local collectors and road head traders.

- Poor access to market information- product price, product chain, end uses, product certification and quality control.

- Poor enterprise development capacity and negotiation or bargaining skills.

- Weak regulation due to poor governance, difficulty in specimen identification, and open Indo-Nepal border.

- Mismatch between royalty rate, market demand, and resource scarcity.

- Non-competitive market due to high transaction costs and poor formal credit facilities. 


\section{Potential Options for Improvement}

There are tremendous opportunities to use this sub-sector as an effective instrument to contribute in poverty reduction in rural villages through increasing investment in supply side, decreasing market transaction costs and increasing local level value addition. Following intervention would be effective to achieve desired outcomes through sustainable harvesting of NTFP:

1. A single species inventory could be simple but NTFP is comprised of multiple species. The existing inventory guideline is not scientifically sound and it can not help much in maintaining MSY. Therefore, a separate inventory guideline for NTFP needs to be prepared.

2. Provide appropriate harvesting techniques and post harvesting skills to the collectors.

3. Capacity building of forestry professionals in resource inventory methods, plant ecology and market analysis to enhance their monitoring skills.

4. The authority needs to sensitize collectors to adopt 'group-sales approach" to shift bargaining power from traders to the collectors

5. Private owners' rights of free access to market, without any legal and procedural hassles, needs to be protected by the forest law and regulation.

6. Forestry professionals have lost their credibility in public, so it is high time to prove their integrity by putting into effect - "ignorance of law is no excuse"

7. Action research to explore low cost domestication techniques, efficient harvesting methods, and effective product handling skills of few potential species that have very high market demand.

8. Develop market linkages between collectors and traders through strengthening access to market price, technology, and micro finance.

9. Revenue from NTFP is not enough, so emphasis should be given in private-public partnership to develop market infrastructure and value addition.

\section{References:}

Acharya, T.P. 2000. Conservation of non-timber forest products (NTFPs) in Humla, Nepal: A case study of Rudikot (Margor) region for Biodiversity conservation. In: Proceedings of the Third Regional Workshop of Community Based NTFP Management, Kathmandu, Nepal. South and East Asian Countries NTFP Network (SEANN). pp. 264-271.

Bhattarai, N.K. and Croucher, J. 1996. Viability of local commercialization of non-timber forest products as a strategy for promoting Biodiversity conservation. In: P.K. Jha, G.P.S. Ghimire, S.B. Karmacharya, S.R. Baral and P. Lacoul (Eds.). Environment and biodiversity in the context of South Asia. Ecological Society, Kathmandu, Nepal. pp. 346-353.

DoF 2002. Hamro Ban, Department of Forest, Kathmandu Nepal.

DoF 2007. Hamro Ban, Department of Forest, Kathmandu Nepal.

FAO 1997. State of the Worlds forests 1997, FAO, Rome, Italy 
Myers, N. 1988. Tropical forests: Much more than stocks of woods. Journal of tropical ecology, 4:209-21

Peters, C.M.et.al 1989. Valuation of Amazonian Rain Forests, Nature, 339: 655-56

Secretariat of CBD 2001. Sustainable management of NTFP, CBD technical series no. 6 , Montreal :SCBD

Wiersum, K.F. 1997. Indigenous exploitation and management of tropical forest resources; and evolutionary continuum in forest- people interaction. Agriculture Ecosystem and Environment 63:1-16

Wong, J. 2000. developing need-based inventory methods for NTFP. Application and development of current research to identify practical solutions for developing countries. Paper submitted in workshop on developing need based inventory methods for NTFP, 4-5 May 2000, FAO

"वन र वन्यजन्तुको संरक्षण गरौं जनतालाई संरक्षणमा प्रत्यक्ष सहभागी गराऔं”

विजया दशमी तथा शुभ-दिपावली २०६प को शुभ उपलक्ष्यमा समस्त संरक्षणप्रेमी एवं उपभोक्ता वर्गहरुमा हार्दिक मंगलमय शुभ-कामना व्यक्त गर्दछौं ।

\section{ख़ातड राष्ट्रिय निकुज्ज कार्यालय परिवार} खप्तड, बाजुरा
"जैविक विविधताको संरक्षण गरों पारिस्थितक अक्षुणता कायम राखों”

\section{विजया दशमी} तथा

शुम-दिपावली २०६६ को शुभ उपलक्ष्यमा

समस्त संरक्षणप्रेमी एवं

उपमोन्ता वर्णहकुमा हार्दिक मंगलमय शुभ-कामना व्यन्त गर्दछौ । पर्सा वन्यजन्तु आरक्ष कार्यालय परिवार आधाभार, वारा फोन नं. ०४३-पू२१०४१ 